\title{
What the people of Utica (Tunisia) ate at a banquet in the 9th century BCE. Zooarchaeology of a North African early Phoenician settlement
}

\author{
João Luís Cardoso ${ }^{a}$, José Luis López Castro ${ }^{\mathrm{b}, *}$, Ahmed Ferjaoui ${ }^{\mathrm{c}}$, Alfredo Mederos Martín ${ }^{\mathrm{d}}$, \\ Víctor Martínez Hahnmüller ${ }^{\mathrm{e}}$, Imed Ben Jerbania ${ }^{\mathrm{c}}$ \\ a Academia das Ciências de Lisboa, Universidade Aberta, Rua da Escola Politécnica, 147, 1261-001 Lisboa, Portugal \\ b Departamento de Geografia, Historia y Humanidades, Universidad de Almería, 04120 Almería, Spain \\ ${ }^{c}$ Institut National du Patrimoine, Ministère de la Culture, 4 Place du Château, 1008 Tunis, Tunisia \\ d Departamento de Prehistoria y Arqueología, Facultad de Filosofía y Letras, Universidad Autónoma de Madrid, Campus de Cantoblanco, 28049 Madrid, Spain \\ e Department of Archaeology, Ghent University, Sint-Pietersnieuwstraat 35, B-9000 Gent, Belgium
}

Keywords:

Archaeozoology

Banquet

9th century

Phoenicians

North Africa

\begin{abstract}
A B S T R A C T
In the paper are presented the results of a faunal set from the recent excavations at the Phoenician colony of Utica (Tunis). The set is composed by 536 fragments of bones found in an abandoned Phoenician water pit, filled intentionally with bones of consumed animals, drinking cups, plates, and bowls, as well as amphorae of Phoenician, Geometric Greek, Sardinian and Lybic productions. The hypothesis is that the well possibly was filled with the remains of a ritual banquet in which oxen, caprinae, pigs, horse and domestic dog were consumed. Another species such as turtle and African elephant complete this ancient faunal set. C14 dating samples from the deposit points to the last quarter of cal 10th century BCE to the middle of cal 9th century BCE, as the initial period of Phoenician presence in the Western and Central Mediterranean. So the faunal remains are for the moment the oldest in a Phoenician settlement in North Africa and Central Mediterranean area.
\end{abstract}

\section{Introduction}

The archaeological site of Utica is $37^{\circ} 03^{\prime} 31 \mathrm{~N}$ and $10^{\circ} 03^{\prime} 47 \mathrm{E}$, on the North of Tunisia, perched on a promontory located at what used to be the mouth of the Bagradas river, which nowadays is completely filled in (Fig. 1) (Delile et al., 2015). Ancient Utica was one of the oldest Tyrian settlements in the Western Mediterranean reaching BC 1110 according to Phoenician traditions passed on by classical literature (Ps. Aristotle, Mir Ausc 134, Flavius Josephus Against Apion I, 18; Velleius Paterculus I, 2, 3, Plin. Nat. His. XVI, 216). Excavations in Utica during the nineteenth and the first half of the twentieth century uncovered the Phoenician-Punic necropolis and the Roman city. New research in 2003 (Ben Jerbania and Redissi, 2014) and the Tunisian-Spanish project launched in 2010 (López Castro et al., 2012, 2014, 2015, 2016) have found remains from a very early Phoenician stage in Utica, testifying the existence of an early colonial horizon. The beginning of Western Phoenician colonization has been archaeologically dated to the first half of the 8th century BCE and extended from Phoenicia to the Iberian

\footnotetext{
* Corresponding author.

E-mail addresses: joao.cardoso@uab.pt (J.L. Cardoso), jllopez@ual.es (J.L.L. Castro), ferjaouiahmed@yahoo.fr (A. Ferjaoui), alfredo.mederos@uam.es (A.M. Martín), Victor.MartinezHahnmuller@UGent.be (V.M. Hahnmüller), ibenjerbania@yahoo.fr (I.B. Jerbania).
}

Peninsula, North Africa, Sicily, Malta and Sardinia. Phoenicians founded colonies to obtain raw materials, to establish trade between western areas and the Levant and for the exploitation of local resources (Aubet, 2009; Bondí et al., 2009). Recent archaeological discoveries in the South of the Iberian Peninsula at Huelva (Gonzalez et al., 2004), La Rebanadilla (Sanchez et al., 2012) and at the sanctuary of El Carambolo have demonstrated the existence of an early colonial horizon from 9th century BCE which has provided C14 calibrated dates between the late 11th and late 9th centuries BCE, changing the chronology of the early Iron Age in the Western Mediterranean. The content of a closed hoard with an interesting collection of ceramic and faunal remains was documented in the 2012-2015 Utica excavations in a reused well, dated to the earliest colonial phase, recording the oldest Phoenician presence in North Africa and Central Mediterranean (López Castro et al., 2016).

\subsection{The archaeological context}

The excavation campaigns carried out in Utica in 2012-2015 uncovered a very ancient Phoenician architectural complex, still in the process of being excavated, made up of a building found in a very upper layer, tampered by old and modern plundering ditches, as well as foundations of other lost buildings. To the south of the building, a deep, almost round circular pit of about three meters in diameter opens up, excavated in the natural clay substrate. The pit reaches $3.94 \mathrm{~m}$ depth from the surface 


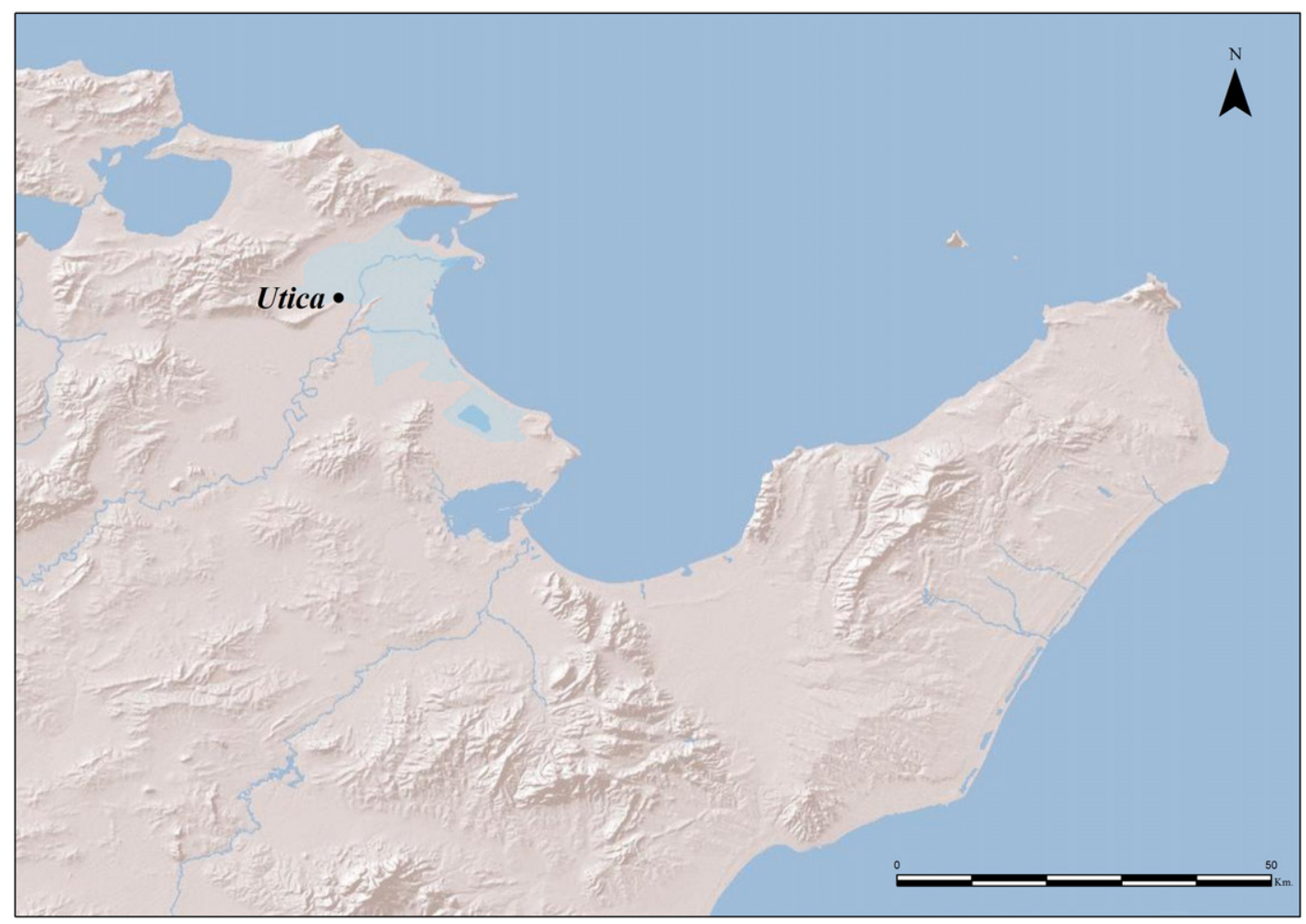

Fig. 1. Situation of Utica. (Ancient Bay of Utica is coloured in blue).

(1.18 $\mathrm{m}$ a.s.l.) (Fig. 2). A rich collection of anthropic remains was found inside: Phoenician, Sardinian, Greek geometric, Villanovian and local Libyan ceramics whose main functions were liquid storage, drinking cups and plates (Fig. 3) (López Castro et al., 2016). Also, abundant faunal and some construction remains like adobe and traces of lime, all compacted in ash- and coal-stained soil, were recovered. Finding these cup fragments deposited at different depths inside the pit and documented evidence of anatomically connected skeletal remains, as well as the chronological uniformity of the ceramic set, evidences that the pit was intentionally filled in a short time. The hypothesis that we admit is that it could possibly be a well given the nature of the geological substrate. Use of water was very important in Phoenician and Punic societies and wells and water pits used to be sacred places and were related to sanctuaries (Groenewoud, 2001: 146). For unknown reasons, perhaps salinization caused by a drought and by its proximity to the

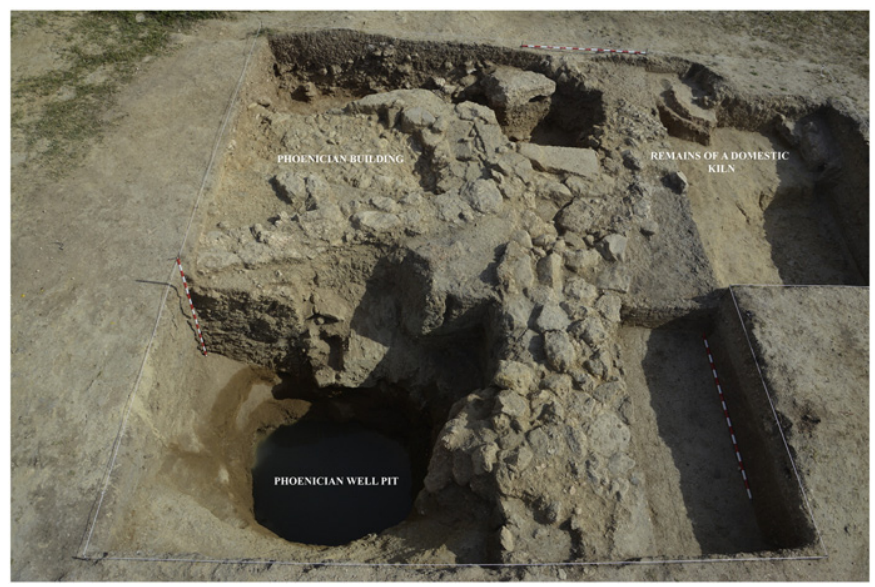

Fig. 2. Archaeological excavation at Utica in 2014 season: the pit well 20,017 besides the remains of a Phoenician building.
Bagradas estuary and the Utica bay, the pit was closed, possibly in a ritualistic way, like other water pits in Phoenician sanctuaries (Nigro, 2014; Spagnoli, 2014). The ritual could imply the celebration of a collective banquet, as the content of the Utica water pit suggests.

\subsection{Radiocarbon dating of the faunal collection and the context}

We have obtained a series of radiocarbon dates on grain seeds from the pit filling in UE 20017 cut 20. The series consists of three very homogeneous radiocarbon datings (Table 1 ).

Maximum oscillation is in 1013-828 cal BCE in Intcal98 or 1025$832 \mathrm{cal}$ BCE in Intcal13 (Reimer et al., 2013): i.e., there is a 95\% chance that the date is between the end of 11th. century cal BCE at the end of 9th century cal BCE in the average probability distribution, while the intercept points in the calibration curve point to the last quarter of 10th century cal BCE, 900-925 cal BCE.

This series is almost identical to the two dates from Phase IV of La Rebanadilla in Malaga (Sanchez et al., 2012: 69) (Table 1). The intercept points on the calibration curve are located between 935 and 900 cal BCE, contemporary to the filling of Utica's 20,017 pit. The Utica and La Rebanadilla dating series points to the last quarter of 10th century cal $\mathrm{BCE}$, or perhaps even the middle of 9th century cal BCE, as the initial period of Phoenician presence in the Western and Central Mediterranean.

\section{Material and methods}

The set studied concerns the mammal remains that have been found till now. From a methodological approach, all dental and bone elements identifiable both at a generic and a specific level (genus and species) have been taken into account, exempting vertebrae and ribs (with exception of the cervical vertebrae, which features are more characteristic). The total Number of Identified Remains is 536 (NIR). The calculation of Minimal Number of Individuals (MNI) was also considered and quantified on the basis of the anatomic element more abundant for each species, although the NIR is in the limit of significance 

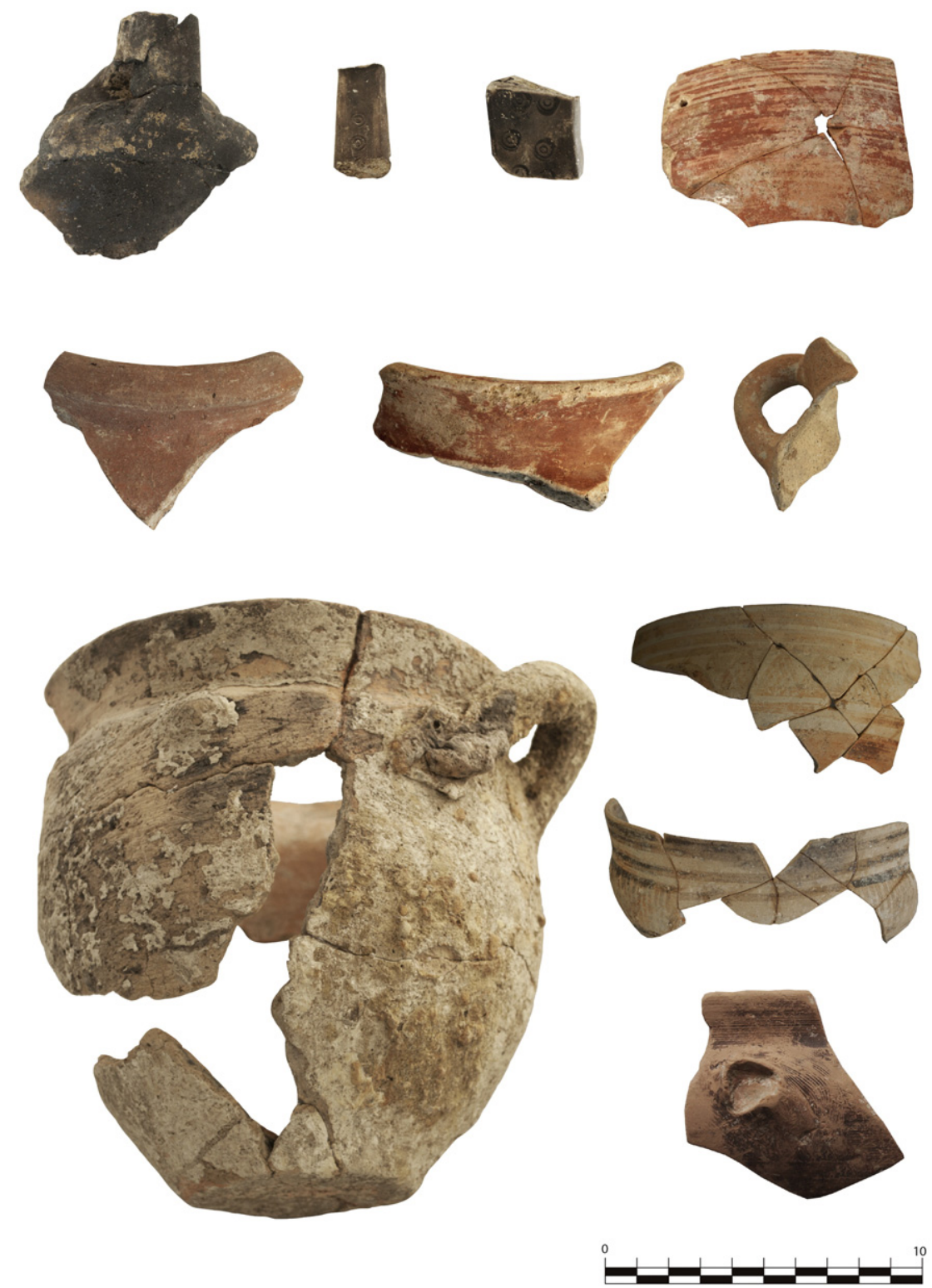

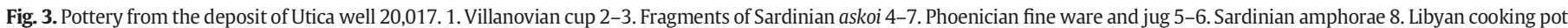
9-11. Greek geometric skiphoi.

for the use of the calculation of the NMI, which we can assume to be ca. 500 NIR. In consequence, in this case the NIR is more reliable than the NMI, bearing in mind that the bones exhibit a similar degree of fracturing in all the species present, and that each one of them has approximately the same number of bone parts (Cardoso, 1995a). We should point out that the criteria adopted to quantify the remains are not always uniform. In this work, each piece identified is counted as a single item; as it is impossible to know the taphonomic history of each fragment, we consider the quantification of each identified individual more adequate, even those that include a single piece, for example a mandible with several teeth, in order to eliminate the influence of post-depositional fractures, or even modern ones produced during the excavation. In fact, what is most important is that the approach taken in each study is consistently applied to the entire sample so that the results obtained in each species could be comparable. Rib fragments, bone chips or vertebral bodies were not counted because of the difficulty or even impossibility of the identification process. This question was object of detailed discussion that support the methodology used in this work (Davis, 1987, 2006; Bar-Oz \& Dayan, 2002; Maron \& Bar-Oz, 2008; Tentracoste, 2009; Detry, Cardoso, Bugalhão, 2016).
Therefore, the composition and features of the faunal set is important to support or not the hypothesis of filling an abandoned water pit during a ceremony associated to a ritual banquet. Comparisons between domestic and sanctuary-related faunal sets in Phoenician and Punic societies with that of the Utica pit are necessary to understand the origin of the deposit. Comparisons of species and ways of consumption are made with the available published material of the short number of faunal sets studied in Western Mediterranean Phoenician sites. More abundant particular studies have been carried out on faunal sets from the Iberian Peninsula, but all of them are later than the sample from Utica, as it is the oldest one studied at the time being.

\section{Results: the faunal collection}

\subsection{Distribution by species}

The 536 identified remains belong to the following species (Table 2):

- Bos taurus (domestic oxen) - $233+32^{*}$ remains ( ${ }^{*}$ from juveniles/ subadults). 
Table 1

C14 datations from Phoenician Utica pit 20017 and Phoenician site of La Rebanadilla (Málaga).

\begin{tabular}{|c|c|c|c|c|c|c|c|}
\hline Site & B.P. & \pm & B.C. & $\max . C A L$ & CAL B.C. & $\min$. CAL & $\mathrm{n}^{0}$ Lab. \& Material \\
\hline Utica (Tunisia), pit 20,017, $-2.77-2.67 \mathrm{~m}$. & 2795 & 35 & 845 a.C. & $\begin{array}{l}1025 \\
1013\end{array}$ & $\begin{array}{l}981-908 \\
967 \\
963 \\
923 \mathrm{AC}\end{array}$ & $\begin{array}{l}842 \\
834\end{array}$ & CNA-2403-AMS/S \\
\hline Utica (Tunisia), pit 20,017, -3.17-3.07 m. & 2765 & 35 & 815 a.C. & $\begin{array}{l}998 \\
1000\end{array}$ & $903 \mathrm{AC}$ & $\begin{array}{l}832 \\
828\end{array}$ & CNA-2402-AMS/S \\
\hline Utica (Tunisia), pit 20,017, $-3.36-3.32 \mathrm{~m}$. & 2790 & 35 & 840 a.C. & $\begin{array}{l}1016 \\
1000\end{array}$ & $\begin{array}{l}981-903 \\
966 \\
964 \\
921 \text { AC }\end{array}$ & $\begin{array}{l}840 \\
833\end{array}$ & CNA-2400-AMS/S \\
\hline $\begin{array}{l}\text { La Rebanadilla Phase IV } \\
\text { Málaga (Spain) }\end{array}$ & 2810 & 40 & 860 a.C. & $\begin{array}{l}1057 \\
1049\end{array}$ & $\begin{array}{l}971 \mathrm{AC} \\
959 \\
936\end{array}$ & $\begin{array}{l}843 \\
835\end{array}$ & Beta-AMS-264.171/C \\
\hline $\begin{array}{l}\text { La Rebanadilla Phase IV } \\
\text { Málaga (Spain) }\end{array}$ & 2780 & 40 & 830 a.c. & $\begin{array}{l}1016 \\
1000\end{array}$ & $917 \mathrm{AC}$ & $\begin{array}{l}830 \\
829\end{array}$ & Beta- AMS-264.170/C \\
\hline $\begin{array}{l}\text { La Rebanadilla Phase I } \\
\text { Málaga (Spain) }\end{array}$ & 2700 & 40 & 750 a.C. & $\begin{array}{l}919 \\
967\end{array}$ & $832 \mathrm{AC}$ & $\begin{array}{l}801 \\
801\end{array}$ & Beta-AMS-264.173/C \\
\hline $\begin{array}{l}\text { La Rebanadilla Phase I } \\
\text { Málaga (Spain) }\end{array}$ & 2610 & 40 & 660 a.C. & $\begin{array}{l}893 \\
895\end{array}$ & $\begin{array}{l}846-750 \\
806 \mathrm{AC}\end{array}$ & $\begin{array}{l}590 \\
790\end{array}$ & Beta-AMS-264.172/C \\
\hline $\begin{array}{l}\text { La Rebanadilla, San Isidro, tomb 9, Phase II } \\
\text { Málaga (Spain) }\end{array}$ & 2660 & 60 & 710 a.C. & $\begin{array}{l}975 \\
919\end{array}$ & $\begin{array}{l}946-755 \\
812 \text { AC }\end{array}$ & $\begin{array}{l}596 \\
765\end{array}$ & Beta-AMS-264.174/M \\
\hline
\end{tabular}

The calculation of the MNI, corresponds to 8 adults and 2 juveniles/ subadults, based on the most abundant anatomic element, the first/second upper molar (M|1-2).

- Ovis/Capra (sheep/goat) - $114+28^{*}$ remains ( ${ }^{*}$ from juveniles/subadults). The MNI obtained: 3 adults and 1 juvenile was also based on the most abundant element, in this case, the distal articular epiphysis of the humerus.

- Sus sp. (Suidae, essentially domestic) - $58+30^{*}$ remains ( ${ }^{*}$ from juveniles/subadults).

The MNI is based on the most abundant element, the scapula for the adults and the upper jaw for the juveniles/subadults, respectively corresponding, to 2 and 4 individuals.

- Equus caballus (horse) - $21+3^{*}$ remains (*from juveniles/subadults). The MNI based on the mandibular bone indicates the existence of 1 adult and 3 juveniles/subadults.

- Canis familiaris (domestic dog) - $10+2^{*}$ remains ( $*$ from juveniles/ subadults). The MNI obtained corresponds to 2 juveniles, based on the upper jaw, and 1 adult.

- Loxodonta africana - 3 remains of 1 or more tusks.

- Testudo sp. (Land Tortoise) - 2 remains.

The large size bovid belongs to the domestic Bos taurus species, but none reaches the size likely to be attributed to the ancestor or auroch (Bos primigenius) species that disappeared from both Portuguese (Cardoso, 2002) and Spanish site inventories (Castaños, 1991) in the Bronze Age. As an exception, some remains found in the Iron Age levels in the Lisbon cathedral were attributed to this species because of its size (Arruda, 1999-2000: 127). It is interesting to note the existence of two different sizes in the individuals, perhaps due to sexual dimorphism, as the selection processes would not yet be developed in that time.

The clear predominance of domestic cattle remains in this community's diet (or part of it), fact is further underlined by the fact that it is an adult bovid of an unimproved race, since these animals were likely to weigh between seven and nine times more than an adult sheep or goat (Antunes, 1991). This means that the actual importance of this species was much larger than what its relative frequency already indicated, representing a long, prevailing source of protein. Bovine cattle could be used to pull carts and plows, and even to get milk, which makes it a species with multiple uses, and therefore its preference in these communities is understandable.

Domestic caprinae (sheep and goats) and swine are just as significant in the diet, and they are permanently available food sources, like cattle. Regarding swine, the conclusion is that these were essentially or even exclusively domestic animals as seems to be indicated by the complete absence of tusks that, by size and morphology, may be attributed to wild boar.

Some osteometric and dental based differentiation criteria between wild and domestic species were already submitted (Payne, Bull, 1988), to be followed more recently by other essentially biometric observations based on certain anatomical segments (Albarella et al., 2005). However, the existing variation in size between domestic and wild individuals depending on the geographic area in question determines the establishment of distinguishing criteria. In this case, as well as in others, consumption of domestic swine by Semitic peoples should not be a surprise, since it is documented in many Phoenician-Punic sites in the Iberian Peninsula (Barros, Cardoso, Sabrosa, 1993; Cardoso, 1995b; Cardoso, 2000; Davis, 2006; Estaca Gómez et al., 2015; Detry, Cardoso, Bugalhão, 2016).

In terms of differentiation between sheep and goats, this is only possible on the basis of some specific elements (Boessnecck, 1969; Payne, 1973; Davis, 2008a), including ossicones, humerus, calcaneum, astragalus and metapodials, as well as some dental features; however, for the intended purpose, which is to describe the food economy of these populations, differentiation, even when possible in some cases, is not essential because in terms of food and function, the role played by both species is identical, and the existence of mixed herds of the two species is frequent. However, the fact that goats are much more resistant to drought and aridity, it is logical that they are predominant in the sample, given the climatic characteristics of the region studied, a similarity that can be verified today.

The three groups of domestic animals discussed were a part of the diet of the community studied. However, it is important to emphasize that the relative presence of each species cannot be seen strictly from an economic perspective, in the framework of a simple food strategy detached from the religious reality of the time, where the consumption of certain animals had a social or even symbolic meaning. The clear importance of domestic cattle consumption is comparatively higher than the reality usually observed in other comparable sets, discussed below, and may, in part, reveal the nature of the landfill, which, as mentioned 
Table 2

Distribution by species and age of faunal remains from pit 20,017

\begin{tabular}{|c|c|c|c|c|c|c|c|c|c|c|c|c|c|c|}
\hline \multirow{2}{*}{$\begin{array}{l}\text { Species } \\
\text { Anatomic } \\
\text { Segments }\end{array}$} & \multicolumn{2}{|c|}{ Bos Taurus } & \multicolumn{2}{|c|}{ Ovis/Capra } & \multicolumn{2}{|c|}{ Sus sp. } & \multicolumn{2}{|c|}{ Equus caballus } & \multicolumn{2}{|c|}{ Canis familiaris } & \multicolumn{2}{|c|}{ Loxodonta africana } & \multicolumn{2}{|c|}{ Testudo sp. } \\
\hline & & Juvenile/subadults & & Juvenile/subadults & & Juvenile/subadılts & & Juvenile/subadults & & Juvenile/subadults & & Juvenile/subadults & & Juvenile/subadults \\
\hline Ossicones & 8 & & 3 & & & & & & & & & & 2 & \\
\hline Upper teeth series & 11 & 2 & 2 & & 6 & 3 & & & & 2 & & & & \\
\hline Isolated upper teeth & 14 & 4 & 3 & 2 & 1 & & & & & & & & & \\
\hline Mandibular bone & 10 & 5 & 2 & 9 & 12 & 6 & 2 & 3 & & & & & & \\
\hline Lower teeth series & 6 & & 13 & 1 & 3 & 2 & 3 & & 1 & & & & & \\
\hline Isolated lower teeth & 23 & 3 & 17 & 1 & 10 & 8 & 3 & & & & 3 & & & \\
\hline Omoplate & 6 & & 9 & 2 & 4 & 1 & & & & & & & & \\
\hline 1st and 2 nd vertebrae & 2 & & 1 & & 1 & & 1 & & & & & & & \\
\hline Coxal & 4 & & & & & & & & & & & & & \\
\hline Humerus & 11 & 3 & 8 & 2 & 5 & 2 & & & 2 & & & & & \\
\hline Ulna & 4 & & 4 & 2 & 2 & 1 & & & & & & & & \\
\hline Radius & 7 & & 9 & & 2 & & & & & & & & & \\
\hline Metacarpal & 15 & 1 & 7 & & & & 3 & & & & & & & \\
\hline Femur & 11 & 3 & 7 & 3 & 1 & 1 & 1 & 1 & & & & & & \\
\hline Kneecap & 2 & & & & & & 1 & & & & & & & \\
\hline Tibia & 12 & 4 & 9 & 1 & 2 & 1 & 1 & & 1 & & & & & \\
\hline Astragalus & 9 & 1 & 5 & 1 & 1 & 1 & & & & & & & & \\
\hline Calcaneal & 6 & 2 & 1 & & 2 & 2 & & & 1 & & & & & \\
\hline Metatarsal & 9 & & 8 & 1 & 3 & & 1 & & 5 & & & & & \\
\hline Carpo-Tarsal bone & 16 & & & & & & & & & & & & & \\
\hline 1st Phalanx & 19 & 2 & 4 & 2 & 3 & 2 & 1 & & & & & & & \\
\hline 2nd Phalanx & 19 & 2 & 2 & 1 & & & 1 & & & & & & & \\
\hline 3rd Phalanx & 9 & & & & & & & & & & & & & \\
\hline NIR/Total & 233 & 32 & 114 & 28 & 58 & 30 & 22 & 4 & 10 & 2 & 3 & 0 & 2 & 0 \\
\hline MNI & 8 & 2 & 3 & 1 & 2 & 4 & 1 & 3 & 1 & 2 & 1 & 0 & 1 & 0 \\
\hline
\end{tabular}




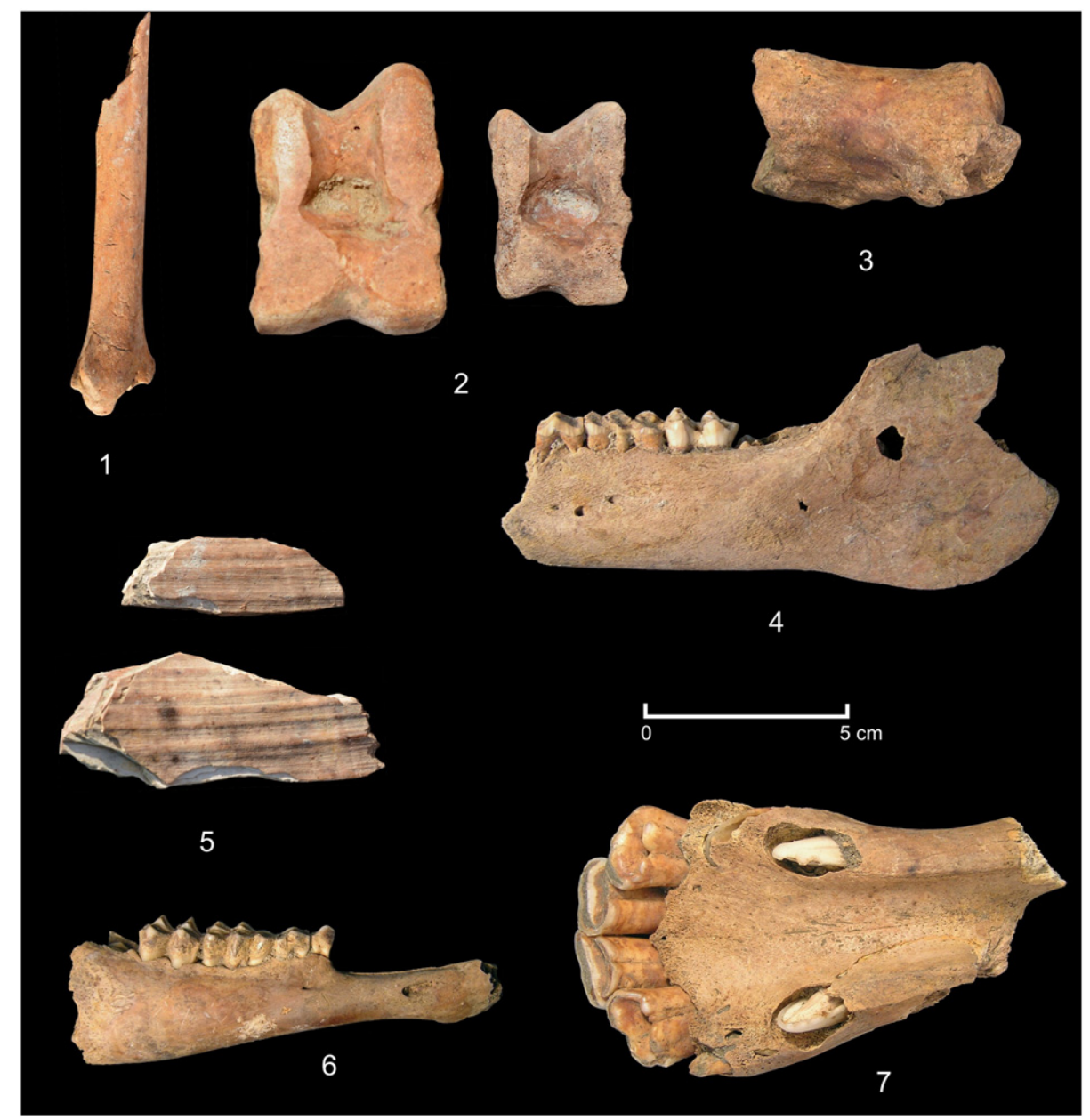

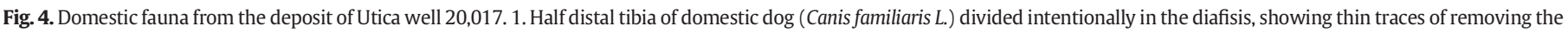

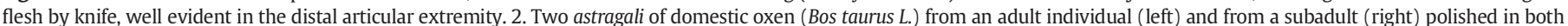

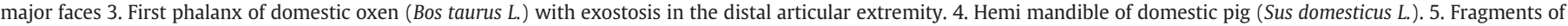

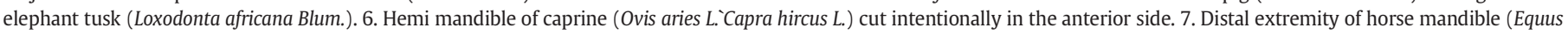
caballus $L$.).

before, should not be considered just a negative structure intended for the reception of undifferentiated domestic waste produced in the surrounding urban areas.

Other domestic animals were sporadically present in this set. This is the case of the horse (See Fig. 4,7), since it corresponds to a species whose main utilization was not for alimentation. On the other hand, the absence of domestic donkey, present, even in small quantities in several Phoenician-Punic environments in the Iberian Peninsula, is worth mentioning, and could be explained by its scarce use in the region at this time. Neverthelless, their presence since the Chalcolithic in the Iberian Peninsula (Cardoso et al., 2013), taking into consideration that it is a species with an Eastern Mediterranean origin, makes possible that they could already be present in the region of Utica during the IX century BCE.

The appearance of three fragments of elephant tusks is significant (See Fig. 4,5). They certainly belong to the African species, Loxodonta africana Blumenbach, 1797, which is divided into two geographical subspecies, the savanna elephant, $L$. africana africana and the forest elephant, $L$. africana cyclotis. The first, at the start of the twentieth century, reached the northern edge of the Sahara through Senegal, Mauritania, Chad and the Sahelian region of Sudan and Somalia. Increasing aridity in North Africa during the Neolithic steadily pushed this subspecies to the South. As for the forest elephant, they currently located in the Congo Basin and a northern coastal strip towards Senegal, although it is possible that, due to wetter weather conditions in the past, they could have reached latitudes close to the Canary Islands. In the Roman period, the forest elephant occupied the litho-Mediterranean strip, from Tripolitania to the Atlantic, bordering to the South with the foothills of the Atlas Mountains (Krzyskowska, Morlot, 2000: 323). According to Pliny the Elder (Nat. His. VII, 11, 32), elephants could still be obtained in North Africa at his time (first century CE. He also writes that the first Roman general who crossed the Atlas found forests full of elephants, confirming the conclusion that the forest subspecies still existed at that time in those latitudes. It was, indeed, in this region, where the Carthaginians got their war elephants, where their extinction was confirmed around the fourth century CE. The remains of tusks found in Utica may represent remnants of raw materials used for ivory crafts, demonstrating the use of a commodity whose use became common shortly after with the full expansion of Phoenician trade.

The presence of the domestic dog is well known in Phoenician-Punic times in relation to practices that go beyond its simple status as a pet and work animal. Present in the Iberian Peninsula in household contexts since the Mesolithic period, its limited number of individuals has to do with the differentiated role played by them and other domestic animals in human communities. The dog feeds on all food scraps. The cutting marks sometimes found in dog remains, as in the Phoenician-Punic era remains of Rocha-Branca, Silves (Cardoso, 1993) are rather associated to sacrifices and not primary consumption (although accepted as 
secondary consumption, associated to ritual practices (whose main purpose was not the consumption in itself). In fact, since the Mesolithic, dog sacrifices have been documented, as shown by the marks preserved in the skull associated to a complete skeleton found in the Mesolithic shell midden of Cabeço da Arruda, Muge, Portugal (Detry, Cardoso, 2010). These sacrifices were extended in time, and there are wellknown examples of this practice with domestic dogs. One of the most important examples was recently identified in a context of the Middle Bronze Age in the north interior of the Iberian Peninsula (Liesau, Esparza Arroyo, Sánchez Polo, 2014). Evidence of ritual practices involving dogs are known in Phoenician and Punic contexts in the Iberian Peninsula (Cardoso, Gomes, 1997; Niveau, Ferrer, 2004; Niveau, 2008). In the few remains that we have studied (See Fig. 4,1), although there are no cut marks, nothing prevents their presence from being associated to the previously mentioned ritual practices. These are medium-sized animals, the size of a Portuguese water dog.

Finally, the two tortoise carapace and plastron fragments probably belong to a Testudo graeca, given the current geographical distribution of the species, which covers the region studied. The fire marks on them show that these animals were cooked by placing them directly over coals.

\subsection{Distribution by age}

Of the total 536 items classified, 96 belong to young or subadult individuals, on the basis of both dental wear (Grant, 1982) and the fusion of the epiphyses, especially in the long bones, according to Table 2.

These results stress the importance of young/subadult individuals killed for consumption, especially swine, followed by caprinae and finally by cattle, also indicated by the NMI of each species, as presented above. The preference for the consumption of such juvenile animals even before they finish growing to the detriment of keeping them for meat production (in the case of suidae), milk, ploughing/transport (in the case of cattle), or even to produce wool (in the case of caprinae), suggests a community with economic capacity, consuming animals once they arrive at the optimum age for the production of meat, when they had the best features for that purpose.

The importance of cattle in the transport of people and merchandises, as well as animal traction, which was certainly relevant at the time, are apparently in contradiction with the fact that the majority of horses are juvenile/subadult; the under-representation of this species in the collection indicates their low importance regarding consumption. The dominant presence of juveniles or sub-adult individuals could be explained by the good conditions offered by the region of Utica for horse breeding, such as vast plains, the presence of water (in the site itself) and, consequently, of food. But their occurrence in this deposit could be correlated to an eventual preference of the consumption of young individuals.

Regarding the domestic dog, despite the dominance of juveniles (2), the higher number of bones belonging to adults indicates that the species could have had a permanent functional role in the community at Utica, as it does today, as a pet and flock guardian. Nevertheless, one calcaneum shows cutmarks, which suggest their consumption, as is the case of the individual from Rocha Branca, Silves, Portugal (Cardoso, 1993), or an alternative use for a ritual sacrifice, common in the Semite word (Cardoso, Gomes, 1997; Niveau, 2008; Niveau, Ferrer Albelda, 2004). We should bear in mind, though, that until recent times, the dog was a species consumed in all of North Africa, including Tunisian territory (Simoons, 1994).

Finally, some bovine bones with pathological deformations were found: this is the case of a first phalanx that had developed arthrosis, due eventually to the frequency in flooded pastures, as it has currently been verified nowadays in the area next to the archaeological site. This feature it is also explicable as a result of the efforts related to traction, in other words to ploughing or transport (Davis, 2006, 2008b), which is not incompatible with the previous explanation.

\subsection{Anatomical distribution}

All the identified species are represented by anatomically representative segments of the different parts of the skeleton, without evidence of over representation of any of them in particular (see Table 2). This means that animal butchering would be done nearby, followed by consumption of the entire carcass and, finally, by depositing the remains in a pre-existing water pit, after its abandonment.

\subsection{Culinary practices}

Only exceptionally there is evidence of fire and, in this case, essentially in cattle bones, a sign that the majority of the remains were cooked rather than barbecued or grilled, where the pieces of meat were directly exposed to the fire. But this last kind of consumption is illustrated by several teeth, humerus, astragalus and phalanges, that show some dark areas related to local carbonization of the bones.

Cooking by boiling meat is also extended to the swine remains, contrary to the most common way they are currently consumed, by direct exposition to fire.

The prevailing practice of cooked stews and casseroles is indirectly confirmed by the fact that the long bones, especially of caprinae, are intentionally cut on both ends, as indicated by the frequent cutmarks made by knifes or cleavers, in order to obtain predetermined portions of meat. Such portions were significantly larger than those used in stews and casseroles today in the south of the Iberian Peninsula, whose tradition goes back to Islamic times. They required the use of large vessels and would not fit into the pots and pans of the Islamic period (Fernandes, Cardoso, Detry, 2012) or the ones used nowadays. It is interesting to note that they resorted to bronze-clad cauldrons at the end of the Bronze Age, related to the practice of the banquet, well known in Atlantic-Mediterranean contexts of that time. This observation is also valid, even more, for the large bovine meat pieces, which frequently show knife-cutting marks, which are a well-defined pattern.

\section{Discussion}

Based on the hypothesis that the faunal remains found may be associated to a ritual deposit filling the old water pit, few comparable elements susceptible to frame this reality are available. Thus, in Malta, the Tas-Silg Phoenician-Punic sanctuary contained a font for ablutions which was clogged between the second half of the second century BCE and the first century (De Grossi, Battafarano, 2012), so it is farfetched to establish comparisons between its fauna and the set being studied. More important for our purposes is the faunal set collected in the Punic levels of area B located outside the temple (Corrado, Bonanno, Vella, 2004). The deposit formation, which contained a large number of vessel fragments of which $16 \%$ matched each other, was attributed to intentional action and is directly related to ritual practices performed there. Indeed, Semitic liturgy required cooking and eating slaughtered animals on the site of the celebration itself, prescribing the subsequent practice of destroying the container used and burying its fragments with the food scraps and ashes (Niveau de Villedary, 2006: 42). Caprinae (sheep and goats) were by far the most abundant animals, being $96 \%$ of the identified remains. The remaining $4 \%$ were bovine bones, although in other parts of the excavation pig remains were found.

Such predominance is consistent with the natural environment of the island, rocky and semi-arid, and shows that these animals were mostly used in sacrificial rituals in the Phoenician-Punic period. In fact, the inscription on the Marseille tariff, located in the sanctuary, often mentions these two animals (Guzzo, 1988; Lipiński, 1993: 261). As in Utica, all anatomical segments are present in the Maltese sanctuary; the carcasses would be dismembered in loco, and then eaten on the spot, as an intrinsic part of the ritual. Fire marks, unusual in the Utica set, are observed only in the parts of the slaughtered animal 
dedicated to the deity; given the low percentage of bone remains with such marks (only $2 \%$ of the total), the authors admit the possibility that such offerings were the soft parts, while the other parts were eaten or cooked. This reality has, as we have seen, clear parallels in Utica, and it is also confirmed in Leviticus as the most common way to eat meat (Guzzo, 1988: 105; Lipiński, 1993: 265-266).

Utica is closer to the Punic cave-shrine of Es Culleram (Ibiza). The predominance of caprinae remains is also clear here; a bovine bone was identified and no swine bones were located, distancing these results from those obtained in Utica. Contrary to what was observed in Malta, all the caprinae cranial remains showed fire marks, proof that it was the part that was offered to the deity. It would seem that the head would be burned in the altar (Morales, 2003). The post-cranial skeleton is represented by all its anatomical segments, indicating the sacrifice of the whole animal, subsequently dismembered by worshipers and priests. As for how these parts were eaten, the abundant amount of fire marks observed (e.g., of the 22 radial remains, 10 show fire marks) indicate the importance of roasting, which is compatible with the limited evidence of bone marrow extraction. As in Utica, and although here the predominant form of consumption is stew, the shafts of long bones were preserved in significantly long segments, indicating that the cuts were intended to pull apart the carcasses rather than to extract bone marrow; indeed, the long bones (radius, femur, metapods) were cut across at mid shaft (Morales, 2013). The age of slaughter varies greatly, but young animals were preferred, followed by adults and subadults, which is not very different from Utica. By contrast, unlike the Utica data, pig remains are completely absent in both the Maltese temple and this cave sanctuary. This reality has its parallel in the lists of animals on sacrificial rolls of the Phoenician-Punic temple, where there is no evidence of that species, and is also found in classical sources regarding the animals that Semitic peoples could eat, where the authors are unanimous on pork.

However, this precept is sometimes broken even in ritual contexts: in Pit 2625 of El Carambolo (Seville), dated in the transitional period between the eighth and the seventh centuries BCE, the 783 identified remains were linked to three oxen, two pigs, seven sheep and a rabbit. In the set belonging to the pit excavated in the same site in 1958, whose exploration ended in 2002, dated about 100 years later than Pit 2625 , pig is present, and both structures are attributed to a deposit where the remains of sanctuary offerings are accumulated, where the relative importance of cattle and goats varies from the 1958 set and the 2002 one (Bernaldez et al., 2010).

In the Punic dig HX-1 of l'Hort d'en Xim, Ibiza (Saña, 1994), where the fill-in level's chronology is dated to the second half of the third century BCE, and whose primary function would be to collect water, pig appears as the most representative species by the number of remains, the second being the domestic dog, some of which have cutting marks. The unusual abundance of domestic dog suggests that the trench filling, after losing its functional character, may have become ritualistic, or that materials from ritual practices carried out in the surrounding area may have been used for filling, as was also found in Utica.

The importance of the pig is further proven when considering Phoenician-Punic domestic contexts. So while in the necropolis in Villaricos (Almería) the presence of horse, rabbit, sheep, goat and cattle was recognized, there were no pig remains (Castaños, 1994; Riquelme, 2001), and in urban areas of that city, the pig/boar was identified in the levels belonging to the fifth and fourth century BCE (Cardoso, 2011). This is consistent with what is observed in Utica and also in several residential Phoenician-Punic sites such as Almaraz and Almada in the Tagus estuary (Barros, Cardoso, Sabrosa, 1993), in the Abul sanctuary-palace (Cardoso, 2000), in the Sado estuary, or at Cerro da Rocha Branca (Cardoso, 1993), in the old Arade estuary. This situation is clear in Andalusian Phoenician contexts: the preference for consuming immature swine was observed in Castillo de Doña Blanca, reaching 4.7\% of the total number of remains identified (Morales et al., 1994); pig being equally abundant at Cerro del Villar, in Toscanos or the Cerro de la Tortuga (Riquelme, 2001, Table 1).

\section{Conclusions}

Certain aspects must be distinguished as of now for future discussion and reflection, based on the identified elements. In the first place, the exclusiveness of domestic fauna, denoting a settled, permanent community attested by the presence of domestic cattle, caprinae and pigs, whenever such specific classification was possible. These species indicate a stable, permanent human community. A clear prevalence of domestic consumption of cattle, based on the number of identified remains, and considering the size of these animals compared to others, from a perspective of food economy, is compatible with the reality identified for other Phoenician-Punic sites in the Iberian Peninsula. This evidence seems to be assumed as one of the main features of the food economy of these Phoenician-Punic populations, now identified in the North African coast of the Western and Central Mediterranean. In addition, the explanation for the remarkable presence of young to subadult individuals, particularly in the caprinae group, could be related to the social and economic composition of this community, without prejudice that it could also be the consequence of a ritual practice such as a banquet. In this case, the participants in this ceremony were different elements of the community, which justify the special characteristics of the consumed animals, selected by its gastronomic quality.

The possibility that the well was reused makes it comparable to the well in Hort d'en Xim, from the third century BCE. Similarly, pig is abundant, contrasting with most of the analyzed Phoenician-Punic ritual deposits, associated to sanctuaries where animal sacrifices took place, where that species does not appear. The situation in inhabited sites is different, where the presence of swine is constant in both the Phoenician and the Punic periods. Thus, the fauna identified in Utica does not suggest that the source of the remains is ritual sacrifice, or even less a sanctuary deposit, although it is compatible with the remains resulting from a social banquet, to which other remains from different urban areas of the archaeological site could be added, notably those located in the vicinity of the structure.

The almost total absence of fire marks on the bones suggests that almost all of the pieces of meat would be stewed; on the other hand, whenever it was possible to assess their size, it was verified that they were incompatible with the size of the containers used by the Islamic populations of Portugal in the Middle Age for cooking caprinae stews. Therefore, it is likely that the containers used were of larger size, compatible with bronze cauldrons, also evoking the social banquet practice, with a long tradition in Atlantic-Mediterranean communities since the end of the Bronze Age.

\section{Acknowledgments}

This paper was developed as a result of the scientific collaboration agreement between the Institut National du Patrimoine of Tunisia and the Centro de Estudios Fenicios y Púnicos. It is too a result of the research projects HAR2011-29880: La ciudad fenicio-púnica de Utica y la presencia fenicia en el Norte de África, and HAR2014-5335-P granted by the Spanish Ministry of Economy and Competitiveness, and the research project HUM-2678 Los inicios de la presencia fenicia en el Sur de la Península Ibérica y en el Norte de África granted by the Junta de Andalucía. Archaeological fieldwork in 2010, 2012 and 2014 seasons were granted by the program of archaeological excavations abroad of the Spanish Ministry of Education and Culture. This paper is part of the activities of the Campus de Excelencia Internacional CEI-Mar at the University of Almería. Authors acknowledge the reviewers for the useful and interesting comments to improve the text of the article.

\section{References}

Albarella, U., Davis, S.J., Detry, C., Rowley-Conwy, P., 2005. Pigs of the 'far west': the biometry of Sus from archaeological sites in Portugal. Anthropologica 40 (2), 27-54.

Antunes, M.T., 1991. Restos de animais no Castelo de Silves (séculos VIII-X). Contribuicão Para o conhecimento da alimentação em contexto islâmico. Estud. Orient. 2, 103-144. 
Arruda, A.M., 1999-2000. Los Fenicios en Portugal. Universidad Pompeu Fabra, Barcelona Aubet Semmler, M.E., 2009. Tiro y las colonias fenicias de Occidente, (Tercera edición Actualizada Y Ampliada). Bellaterra, Barcelona.

Bar-Oz, G., Dayan, T., 2002. After 20 years. A taphonomic re-evaluation of Nahal Hadera V, an Epipalaeolithic site on the Israeli coastal plain. J. Archaeol. Sci. 29, 145-156.

Barros, L., Cardoso, J.L., Sabrosa, A., 1993. Fenícios na margem sul do Tejo. Economia e integração cultural do povoado do Almaraz, Almada. Estud. Orient. 4, 143-181.

Ben Jerbania, I., Redissi, T., 2014. Utique et la Méditerranée centrale à la fin du IXe s. et au VIIle s. av. J.-C.: les enseignements de la céramique grecque géometrique. Vol. 42. Rivista di Studi Fenici, pp. 177-204.

Bernáldez Sánchez, E., García-Vinas, E., Ontiveros Ortega, E., Gómez Morón, A., Ocaña García de Veas, A., 2010. Del mar al basurero: una historia de costumbres. In: De la Bandera Romero, M.L., Ferrer Albelda, E. (Eds.), El Carambolo. 50 Años de un Tesoro. Universidad de Sevilla, Sevilla, pp. 345-385.

Boessneck, J., 1969. Osteological differences between sheep (Ovis aries Linné) and goat (Capra hircus Linné). In: Brothwell, D.R., Higgs, E.S. (Eds.), Science in Archaeology: A Comprehensive Survey of Progress and Research. Thames \& Hudson, London, pp. 331-358.

Bondì, S.F., Botto, M., Garbati, G., Oggiano, I., 2009. Fenici e Cartaginesi: Una civiltà mediterránea. Istituto Poligrafico e Zecca dello Stato, Roma.

Cardoso, J.L., 1993. Contribuição para o conhecimento da alimentação em contexto fenício. Estudo dos restos da Rocha Branca (Silves). Estud. Orient. 4, 109-126.

Cardoso, J.L., 1995a. A fauna de mamíferos da época muçulmana das mesas do Castelinho (Almodôvar). Materiais das campanhas de 1989-1992. Arqueologia Medieval 3 , 201-220.

Cardoso, J.L., 1995b. Fenícios e indígenas em Rocha Branca, Abul, Alcácer do Sal, Almaraz e Santarém. Estudo comparado dos mamíferos. Aubet-Semmler, M. E., Barthelemy, M. (coords), Actas IV Congreso Internacional de Estudios Fenicios y Punicos (Cadiz, 1995) 1. Universidad de Cádiz, Cádiz, pp. 319-327.

Cardoso, J.L., 2000. Les mammifères d'Abul. In: Mayet, F., Tavares da Silva, C. (Eds.), L'Établissement phénicien d'Abul (Portugal). Diffusion De Boccard, Paris, pp. 281-291.

Cardoso, J.L., 2002. Arqueofaunas: balanço da sua investigação em Portugal. Arqueologia e História 54, 281-298.

Cardoso, J.L., 2011. A fauna de mamíferos de Villaricos: materiais recolhidos na campanha de 1987. In: López Castro, J.L., Martínez Hanmüller, V., Moya Cobos, L., Pardo Barrionuevo, C. (Eds.), Baria I Excavaciones arqueológicas en Villaricos. La excavación de urgencia de 1987. Editorial Universidad de Almería, Almería, pp. 145-150.

Cardoso, J.L., Varela Gomes, M., 1997. O consumo de cão, em contextos fenício-púnicos, no território português. Estud. Orient. 6, 89-117.

Cardoso, J.L., Vilstrup, J., Eisenmann, V., Orlando, L., 2013. First evidence of Equus asinus L. in the Chalcolithic disputes the Phoenicians as the first to introduce donkeys into the Iberian Peninsula. J. Archaeol. Sci. 40, 4483-4490.

Castaños, P., 1991. Animales domésticos y salvajes en Extremadura. Origen y evolución, Revista de Estudios Extremeños. Vol. 47, pp. 9-67.

Castaños, P., 1994. Estudio de la fauna de la necrópolis de Villaricos (Almería). Archaeofauna 3, 1-12.

Corrado, A., Bonanno, A., Vella, N.C., 2004. Bones and bowls: a preliminary interpretation of the faunal remains from the Punic levels in Area B, at the temple of Tas-Silg, Malta In: Jones O'Day, S., Van Neer, W., Ervynck, A. (Eds.), Behaviour behind Bones: The Zooarchaeology of Ritual, Religion, Status and Identity. Oxbow Books, Oxford, pp. $47-53$

Davis, S.J.M., 1987. The Archaeology of Animals. Yale University Press, New Haven.

Davis, S.J.M., 2006. Faunal Remains from Alcáçova de Santarém, Portugal. Instituto Português de Arqueologia, Lisboa.

Davis, S.J.M., 2008a. Zooarchaeological evidence for Moslem and Christian improvements of sheep and cattle in Portugal. J. Archaeol. Sci. 35 (4), 991-1010.

Davis, S.J.M., Gonçalves, M.J., Gabriel, S., 2008b. Animal Remains from a Moslem Period (12th/13th Century AD) Lixeira (Garbage Dump) in Silves. Vol. 11. Algarve, Portugal, Revista Portuguesa de Arqueología, pp. 183-258.

De Grossi Mazzorin, J., Battafarano, M., 2012. I resti faunistici provenienti dagli scavi di Tas Silg a Malta: testimonianze di pratiche rituali. In: De Grossi Mazzorin, J., Saccà, D., Tozzi, C. (Eds.), Atti del $6^{\circ}$ Convegno Nazionale di Archeozoologia, San Romano in Garfagnana, 2009. Associazione Italiana di Archeozoologia-Università di Pisa, pp. 357-363.

Delile, H., Abdelhakim Abichou, A., Gadhoum, A., Goiran, J.-P., Pleuger, E., Monchambert, J.-Y., Wilson, A., Fentress, E., Quinn, J., Ben Jerbania, I., Ghozzi, F., 2015. The geoarchaeology of Utica (Tunisia): the palaeo-geography of the Mejerda delta and hypotheses concerning the location of the ancient harbor. Geoarchaeology 30, 291-306.

Detry, C., Cardoso, J.L., 2010. On some remains of dog (Canis familiaris) from the Mesolithic shell-middens of Muge, Portugal. J. Archaeol. Sci. 37 (11), 2762-2774.

Detry, C., Cardoso, J.L., Bugalhão, J., 2016. A alimentação em Lisboa no decurso da Idade do Ferro: resultados das escavações realizadas no Núcleo Arqueológico da Rua dos Correeiros. Spal 25, 67-82.

Estaca Gómez, V., Yaravedra Sainz de los Terreros, J., Gener Basallote, J.M., Navarro García, M.A., Pajuelo Sáez, J.M., Torres Ortiz, M., 2015. Zooarqueología de los macrovertebrados del yacimiento fenicio del teatro Cómico (Cádiz). Spal 24, 55-76.

Fernandes, I.C.F., Cardoso, J.L., Detry, C., 2012. Cozinhar e comer no Castelo medieval de Palmela. In: Gómez Martínez, S. (Ed.), Memória dos sabores do Mediterrâneo. Campo Arqueológico de Mértola, Mértola, pp. 113-127.

Gonzalez de Canales, F., Serrano Pichardo, L., Llompart Gómez, J., 2004. El emporio fenicio precolonial de Huelva (ca. 900-770 a.C.). Biblioteca Nueva, Madrid.

Grant, A., 1982. In: Wilson, B., Grigson, C., Payne, S. (Eds.), The Use of Tooth Wear as a Guide to the Age of Domestic Ungulates. Ageing and Sexing Animal Bones from Archaeological Sites. BAR, Oxford, pp. 91-108.
Groenewood, E.M.C., 2001. Use of Water in Phoenician Sanctuaries. Vol. 38. Ancient Near Eastern Studies, pp. 139-159.

Guzzo Amadasi, M.J., 1988. Sacrifici e banchetti: Bibbia ebraica e iscrizioni puniche. In: Grottanelli, C., Parise, N.F. (Eds.), Sacrificio e società nel Mondo Antico. Edizione Laterza, Bari, pp. 97-122.

Krzyszkowska, O., Morlot, R., 2000. In: Nicholson, P.T., Shaw, I. (Eds.), Ivory and Related Materials. Ancient Egyptian Materials and Technology. Cambridge University Press, Cambridge, pp. 321-331.

Liesau von Lettow-Vorbech, C., Esparza Arroyo, A., Sánchez Polo, A., 2014. ¿Huesos en La Basura O Deposito Ritualizado? Los Perros Descuartizados de La Huelga (Dueñas, Palencia). Zephyrvs Vol. 74, 2 pp. 89-115.

Lipiński, E., 1993. Rites et sacrifices dans la tradition phénico-punique. In: Quaegebeur, J. (Ed.), Ritual and Sacrifice in the Ancient Near East. Proceedings of the International Conference Organized by the Katholieke Universiteit Leuven 1991. Peeters, Leuven, pp. 257-281.

López Castro, J.L., Ferjaoui, A., Peña Ruano, J.A., Teixidó Ullod, T., Ghazouami, M., Adroher, A., Ben Nejma, M., 2012. Proyecto Utica. Informe de los trabajos arqueológicos efectuados en la ciudad fenicio-púnica de Utica (Túnez). Campaña de 2010. Informes y trabajos 7, 360-371.

López Castro, J.L., Ferjaoui, A., Adroher, A., Arbi, F., Ben Jerbania, I., Dridi, F., Essaadi, F., Ferrer Albelda, E., Fumadó, I., Martínez Hahnmüller, V., Mederos, A., Pardo Barrionuevo, C.A., Peña Romo, V., Sánchez Moreno, A., 2014. Proyecto Útica. Investigación en la ciudad fenicio-púnica. Informes y trabajos 11, 201-219.

López Castro, J.L., Ferjaoui, Ben Jerbania, I., Jendoubi, K., Ferrer Albelda, E., Fumadó Ortega, I., Martínez Hahnmüller, V., Pardo Barrionuevo, C.A., Sánchez Moreno, A., Fumadó Ortega, I., Mederos Martín, A., Carpintero Lozano, S., Dhibi, C., Maldonado López, G. Mora Serrano, B., Niveau de Villedary, A., Peña Romo, V., Souissi, I., Khalfalli, W. Ruiz Cabrero, L.A., Dridi, F., y Essaadi, F., 2015. Proyecto Utica. Excavaciones en la ciudad fenicio-púnica. Campañas de 2013 y 2014. Informes y trabajos 12, 259-280.

López Castro, J.L., Ferjaoui, A., Mederos, A., Martínez Hahnmüller, V., Ben Jerbania, I., 2016. La colonización fenicia inicial en el Mediterráneo central. Nuevas excavaciones arqueológicas en Utica (Túnez). Trab. Prehist. 73 (1), 68-89.

Marom, N., Bar-Oz, G., 2008. Measure fot measure: a taphonomic reconsideration of the Kebaran site of Ein Gev I, Israel. J. Archaeol. Sci. 35, 214-227.

Morales Pérez, J.V., 2003. Estudio de la fauna de la cueva-santuario púnica de Es Culleram (Sant Joan, Eivissa). Saguntum 35, 113-122.

Morales Pérez, J.V., 2013. Sacrificios de animales en Es Culleram (Ibiza) y otros lugares de culto púnicos en el Mediterráneo: aproximación al hecho ritual desde la Zooarqueología. VI Congresso Internacioal de Estudos Fenícios e Púnicos (Lisboa, 2005). Actas Vol. 1. Centro de Arqueologia da Universidade de Lisboa, Lisboa, pp. 342-349.

Morales, A., Cereijo, M.A., Brannstom, P., Liesau, C., 1994. The Mammals. Castillo de Doña BlancaArchaeoenvironmental Investigations in the Bay of Cadiz, Spain (750500 BCE). Archeo Press, Oxford, pp. 37-79.

Nigro, L., 2014. Il primo stanziamento fenicio a Mozia: Nuovi dati dall'area sacra del Kothon. In: Lemaire, A. (Ed.), Phéniciens d'Orient et d'Occident. Mélanges Josette Elayi, Maissoneuve, Paris, pp. 491-504.

Niveau de Villedary y Mariñas, A.M., 2006. Banquetes rituales en la necrópolis púnica de Gadir. Gerion 24, 35-64.

Niveau de Villedary y Mariñas, A.M., 2008. ¿Compañero en la muerte o guía hacia más allá? El perro en la liturgia funeraria púnica. In: Ferrer Albelda, E., Mazuelos, J. Escacena, J.L. (Eds.), De dioses y bestiasAnimales y religión en el Mundo Antiguo. Universidad de Sevilla, Sevilla, pp. 93-137.

Niveau de Villedary y Mariñas, A.M., Ferrer Albelda, E., 2004. Sacrificios de cánidos en la necrópolis púnica de Cádiz. Huelva Arqueológica 20, 63-88.

Payne, S., 1973. Kill-off patterns in sheep and goats: the mandibles from Așvan Kale. Anatol. Stud. 23, 281-303.

Payne, S., Bull, G., 1988. Components of variation in measurements of pig bones and teeth, and the use of measurements to distinguish wild from domestic pig remains. Archaeozool. 2 (1), 27-66.

Reimer, P.J., Bard, E., Bayliss, A., Beck, J.W., Blackwell, P.G., Bronk Ramsey, C., Buck, C.E Cheng, H., Edwards, R.L., Friedrich, M., Grootes, P.M., Guilderson, T.P., Haflidason, H., Hajdas, I., Hatté, C., Heaton, T.J., Hoffmann, D.L., Hogg, A.G., Hughen, K.A., Kaiser, K.F., Kromer, B., Manning, S.W., Niu, M., Reimer, R.W., Richards, D.A., Scott, E.M., Southon, J.R., Staff, R.A., Turney, C.S.M., y van der Plicht, J., 2013. IntCal13 and Marine13 radiocarbon age calibration curves $0-50.000$ years cal BP. Radiocarbon 55 (4), 1869-1887

Riquelme Cantal, J.A., 2001. Ganadería fenicio-punica: un ensayo crítico de sínteses. De la Mar y de la tierraProducciones y productos fenicio-púnicos. Museo Arqueológico d'Eivissa y Formentera, Eivissa, pp. 111-120.

Saña, M., 1994. Análisis zooarqueológico del Pozo HX-1. Ramon, J., El pozo púnico del Hort d'en Xim (Eivissa)Conselleria de Cultura. Educació i Esports, Eivissa, pp. 71-81.

Sánchez Sánchez-Moreno, V., Galindo, L., Juzgado, M., Dumas, M., 2012. El asentamiento fenicio de la Rebanadilla a finales del siglo IX A.C. In: García Alfonso, E. (Ed.), Diez años de Arqueología Fenicia en la Provincia de Málaga (2001 - 2010)María del Mar Escalante Aguilar in Memoriam. Junta de Andalucía, Málaga, pp. 67-85.

Simoons, F.J., 1994. Eat not this Flesh. Food Avoidances from Prehistory to the Present. The University of Wisconsin Press, Wisconsin.

Spagnoli, F., 2014. Phoenician cities and water: the role of the sacred sources in the urban development of Motya, Western Sicily. In: Tvedt, T., Oestigaard, T. (Eds.), Water and UrbanizationA History of Water Series III vol. 1. I.B. Tauris, London-New York, pp. 89-106.

Tentracoste, A., 2009. Sometimes less is more. Comparison of Rapid and Traditional Recording Methods: Bantycock Mine, Balderton. Dissertation. University of Sheffield Master 